Araștırma Makalesi - Gönderim Tarihi: 9 Eylül 2019 - Kabul Tarihi: 19 Aralık 2019

\title{
Laban Hareket Analiz (LMA) Yöntemi ile 3 Boyutlu Bilgisayar Animasyonu Hareket Analizi: “Rafadan Tayfa” TV Serisi Incelemesi
}

\author{
Yasin ARSLAN ${ }^{1}$ \\ Çiğdem TAȘ ALICENAP2
}

\begin{abstract}
Öz
Animasyon sinemasında hareket estetiği ve duygu aktarımı tarihsel süreç içerisinde incelendiğinde, zaman içerisinde teknolojiyi koşut şekilde geliştiği ve dönüştüğü görülmektedir. İlk örneklerinde metamorfoza dayanan hareketlendirme süreci günümüz animasyon sinemasında karmaşık ve çok katmanlı bir yapıya dönüşmüştür. Bu karmaşık çok katmanlı hareketlendirme süreci ise canlandırma sanatçıları için aşılması gereken bir zorluk olarak görülmektedir. Karşılaşılan bu zorlukların ve eksikliklerin giderilmesi amacıyla zaman içerisinde farklı yöntemler ve multi-disipliner çalışmalar yapılmıştır. 1930'lu yıllarda "kuvveti çizmek" ile başlayan çözüm arayışlarını, "kişileştirme" kavramı, "animasyonun elemanları" çalışmaları, oyunculuk tekniklerinden "Stanislavski Sistemi" ve "LMA yöntemi"nin animasyon sinemasına uyarlama çabaları, takip etmiştir. Bu çalışmalardan "LMA yöntemi”hin, hareketlendirme sürecinde canlandırma sanatçısına karakterin iç dünyası ve hareketleri arasında bağlantının kurulmasında ve estetik hareket tasarımında çözüm sunduğu düşünülmektedir. 2000 sonrası Türk çizgi film sektöründe yaşanan gelişmeler sonucunda uzun metraj ve TV dizi serisi birçok proje üretilmektedir. Türkiye'de üretilen bu projelerde de hareketlendirme sürecinin karmaşıklığının bir sonucu olarak, yaratılan karakterin iç dünyası ve hareket tasarımları arasında ilişkinin kurulmasında benzer zorluklar yaşandığı söylenebilir. Bu noktadan hareketle, bu çalışmada Türk çizgi film projelerinden "Rafadan Tayfa"nın hareket tasarımları LMA yöntemi kullanılarak incelenmiş, karakterin iç dünyası ile oyunculuk/ performans tasarımlarının tutarlılıkları gözlemlenmiş ve varsa hareketlendirme sürecindeki eksikler tespit edilerek raporlanmıştır.
\end{abstract}

Anahtar Sözcükler: Çizgi film (animasyon), hareket tasarımı, LMA yöntemi, animasyon sinemasında oyunculuk.

Atıf: Arslan, Y. ve Taș Alicenap, C. (2019). “Laban Hareket Analiz (LMA) Yöntemi ile 3 Boyutlu Bilgisayar Animasyonu Hareket Analizi: "Rafadan Tayfa" TV Serisi İncelemesi". Akdeniz Üniversitesi Iletișim Fakültesi Dergisi, (AKiL) Aralık (32), s. 710-733

1 Arş.Gör. , Anadolu Üniversitesi, Güzel Sanatlar Fakültesi, Çizgi Film/Animasyon Bölümü, yasin_arslan@anadolu.edu.tr ORCID No: 0000-0003-1341-3608

2 Dr. Öğretim Üyesi. , Anadolu Üniversitesi, Güzel Sanatlar Fakültesi, Çizgi Film/Animasyon Bölümü, ctas@anadolu.edu.tr. ORCID No: 0000-0001-9893-1070

Bu çalışma "Animasyon Sinemasında Laban Hareket Analizinin (LMA) duygu aktarımında kullanımı: 3 boyutlu bilgisayar animasyon sahnesi örneği” konulu yüksek lisans tezinden yola çıkılarak üretilmiştir (Arslan, 2019). 


\title{
Motion Analysis of 3D Computer Animation by Using Laban Motion Analysis (LMA) Method: Review of “Rafadan Tayfa" TV Series ${ }^{3}$
}

\begin{abstract}
When motion aesthetics and emotion transfer in animation cinema are examined in the historical process, it is seen that they develop and transform in parallel with technology in time. The animation process based on metamorphosis in the early examples has turned into a complex and multi-layered structure in today's animation cinema. This complex multi-layered animation process is seen as a challenge for animation artists. In order to overcome these difficulties and deficiencies, different methods and multi-disciplinary studies have been conducted over time. The search for solutions that started with "drawing the force" in the 1930s was followed by the concept of "personality", studies of "elements of animation", and the adaptation of the acting techniques named "Stanislavski System" and the "LMA method" to animation cinema. It is thought that the LMA method offers solutions to the animation artist in the process of animating the connection between the character's inner world and movements, and aesthetic motion design. As a result of the developments in Turkish cartoon sector after 2000, many projects of feature films and TV series have been produced. In the projects produced in Turkey, similar difficulties are existing to establish the relationship between the inner world of the created character and the movement design as a result of the complexity of the animating process. From this point of view, in this study, the movement designs of a Turkish cartoon project named "Rafadan Tayfa" were examined by using LMA method, the consistency of character's inner world and acting/performance designs were observed, and any deficiencies in the animation process were identified and reported.
\end{abstract}

Keywords: Animation, motion design, Ima method, acting in animation cinema.

\section{Giriș}

Animasyon sinemasının tarihsel gelişim sürecine bakıldığında başlangıçta temel problemin "hareket" ve "hareketin kaydedilmesi" olduğu görülmektedir. Hareketin kaydedilmesi sürecinde kamera karşısına konulan imaj soyutlanarak, stilize bir şekilde ve farklı teknikler kullanılarak yeniden üretilmektedir. Bu yeniden üretim sürecine konu olan görüntü, içerik olarak ele alındığında arka plan ve karakter olmak üzere iki farklı kategoride değerlendirilmektedir. Arka plan ve animasyon karakteri arasındaki ilişkiye dikkat çeken Furniss, her ikisinin de estetik açıdan eşit öneme sahip olsalar da, seyircinin öncelikle karaktere odaklandığını vurgulamaktadır (1998, s. 66). Bu kapsamda, işlevi açısından arka planın ortamı hazırlayıp seyircide gerekli algıyı yaratarak, seyircinin odağındaki karakteri desteklediğine yer verilir. Odaktaki animasyon karakterinin yaratımında en önemli etkenlerden biri ise onun performans/oyunculuk estetiğidir. Animasyon sinemasında, karakterin performans/oyunculuk estetiği incelendiğinde

3 This study is based on the thesis on "The Use of Laban Movement Analysis (LMA) in Emotion Transmission in Animation Cinema: Example of 3 Dimensional Computer Animation Stage" (Arslan, 2019). 
teknolojiye koşut bir şekilde geçmişten bugüne geliştiği ve dönüştüğü günümüzde ise karmaşık bir süreç haline geldiği görülmektedir. Animasyon sinemasında yapılan çalışmalarda karakterin hareket estetiğinin yaratılmasında temelde iki farklı yaklaşım sergilendiği görülmektedir. Bunlardan ilkinde Animasyonun 12 Prensibi, Animasyonun Elemanları (Elemenent of Animation) ve Animasyonun 21 Temelinde (21 Foundation of Animation) olduğu gibi animasyon sinemasına özgü hareket estetiğinin üretimine odaklanılmaktadır. İkincisinde ise, "kişiselleştirme” (personality) ve Stanislavski'nin oyunculuk teknikleri gibi yöntemler kullanılarak animasyon karakterinin iç dünyası tasarlanmaya çalışılmaktadır.

Animasyon sinemasına özgü hareket estetiğinin üretiminde 1920'li yıllarda Disney Stüdyoları'nın yoğun laboratuvar çalışmaları sonucunda ortaya koyduğu ve hareket estetiği üzerine yapılan çalışmalardan ilki olan Animasyonun 12 Prensibi ${ }^{4}$ o günden bugüne hareketlendirme sürecinde temel alınmaktadır. Animasyon sinemasında hareketi yeniden üretmek için kullanılan Animasyonunun 12 Prensibi; esneme ve gerilme (stretch and squash), ön hareket (anticipation), sahneleme (staging), dosdoğru ve pozdan poza hareket (straight ahead action and pose to pose), takip eden ve bindirmeli hareket (follow through and overlapping action), yavaşlama ve hızlanma (slow in ve slow out), yaylar (arcs), ikincil hareket (secondary action), zamanlama (timing), abartı (exagration), katı/boyutlu çizim (solid drawing), cazibe/çekicilikdir (appeal) (Thomas \& Johnston, 1981). Bu prensipler özünde animasyon sinemada gerçeğe yakın ya da animatik hareket desenlerinin üretilmesine olanak sağlamaktadır. Animasyonun 12 Prensibi Max Flechier'in rotoskop tekniği üzerinden geliştirilmiştir. Rotoskop tekniği önceden kaydedilmiş gerçek hayattan alınan kesitlere ait görüntülerin mekanik bir düzenek ile yeniden çizilmesi prensibine dayanır. Bu teknik, önceden kaydedilmiş görüntüler üzerine odaklanması nedeniyle hareketin arkasındaki duygu, düşünce ve dürtüyü göz ardı eder. Bu sebeple hareket, karakter tarafından gerçekleştirilirken karakterin duygu ve düşüncesinden bağımsız olarak oluşturulur. Oysa gerçek hayatta insanları harekete geçiren iç dünyalarındaki duygu, düşünce ve dürtülerdir. Rotoskop tekniğinden yola çıkarak geliştirilen Animasyonun 12 Prensibi de bu noktada hareketi yaratan duygu, düşünce ve dürtüyü yansıtmada eksik kalmaktadır. Disney Stüdyoları'nın bu eksikliği gidermek için farklı çalışmalar yaptığı bilinmektedir. Bunlardan biri Don Graham'ın Disney Stüdyoları'nda animasyon sanatçılarına verdiği eğitimlerde kullandığı "kuvveti çizme"(drawing the force) çalışmasıdır (Hooks, 2003, pp. 57-58). Bu çalışmada temel amaç karakterin iç dünyasının hareket desenlerine yansıtılmasını sağlamaktır.

Animasyonun 12 Prensibi, 2000'li yılların ortasında Peter Ratner tarafından genişletilerek Animasyonun Elemanları ${ }^{5}$ ortaya konmuştur. Bu gelişmenin temelinde 3 boyutlu bilgisayar animasyonun ortaya çıkması ve popülerleşmesi etkili olmuştur. Ratner yaptığı çalışmada Animasyonun 12 Prensibi ile onun uzantısı olarak tanımladığı

4 Animasyonun 12 prensibinden; dosdoğrul pozdan poza hareket, yaylar, ikincil hareket, zamanlama gibi prensipler hareketin üretiminde ve stilize edilmesinde kullanılmaktadır. Çekicilik, sahneleme ve abartı gibi prensipler ise hareketi yaratan duygu, düşünce ve dürtüyü genel bir çerçevede yakalamak için kullanılmasına rağmen duygu ve düşüncelerle karakterin hareket desenleri arasında bağlantı kurmakta yetersiz kalmaktadır. Animasyon üretiminin temelini oluşturan "Animasyonun 12 Prensibi" hakkında detaylı bilgi için "The Illusion of Life Disney Animation" kitabına bakınız (Thomas \& Johnston, 1981)".

5 Peter Ratner tarafından geliştirilen Animasyonun Elemanları (The Element of Animation), "Animasyonun 12 Prensibi"nin üzerine inşa edilmiştir. Detaylı bilgi için "3-D Human Modelling and Animation" kitabına bakınız (Ratner, 2003, s. 302). 
Animasyonun Elemanları arasındaki doğrudan ilişkiyi vurgulamaktadır. Eylem ve eylemin amacı arasında kurulacak ilişkiye dikkat çekmektedir. Örneğin hız ve etki/patlama (pasing and impact), hareket ve karşı hareket (action and reaction) elemanlarının ön hareket ilkesi ile bağlantılı olduğuna yer verir. Buradan yola çıkarak ön hareketin, ana hareketteki eylemin tersi yönde olması gerektiğine işaret eden Ratner, bunu tenis örneği üzerinden açıklar. Bir tenisçi topa vurmadan önce raketini geriye doğru çeker ve sonrasında hızla topa doğru yönlendirir. Topa vurduktan sonra ise hareketine devam ederek etki alanını geçer ve başlangıç pozisyonuna geri döner (Ratner, 2003, s. 302-306). Ratner, bu örnekte Animasyonun 12 Prensibinden ön hareketi genişleterek ele almıştır. Benzer yaklaşımları geliştirmiş olduğu diğer elemanlarda da sergiler. Ratner'ın yaptığı bu çalışmada animasyon üretiminin estetik açıdan geliştirilmesinin hedeflendiği görülmektedir.

Ratner'ın çalışmalarına benzer bir yaklaşım animasyon sanatçısı Dermot O'Connor tarafından 2018 yılında yayımlanan "Animasyonun 21 Temelib" çalışmasında da görülmektedir (O’Connor, 2018). O'Connor yaptığı çalışmada, Animasyonun 12 Prensibi'nin tamamını ve Animasyonun Elemanları'nın bir kısmını ele almış buna ek olarak oyunculuk ve pandomim (acting and pantomime), siluet (silhouette), eklemleri kırma (breaking joints) gibi yeni temellere yer vermiştir. O'Connor'ın yaptığı bu çalışmada 2 boyutlu geleneksel animasyonun hareket estetiğinin geliştirilmesinin hedeflendiği görülmektedir. Örneğin Animasyonun 12 Prensibi'nden yaylar, çekicilik, ön hareket ve sahneleme prensiplerine, O'Connor tarafından hareket çizgisi\&tersine hareket (line action\&reversal) temeli altında bir arada kullanımına yer verildiği görülmektedir. Benzer şekilde abartı prensibi, abartı/karikatür fiziği olarak ele alınmaktadır.

Animasyon sinemada karakterin hareket estetiğine yönelik gerçekleştirilen bu çalışmaların yanı sıra animasyon karakterlerinin iç dünyasını tasarlamaya yönelik çalışmalar da gerçekleştirilmiştir. John Lasseter'ın "kişiselleştirme (personality)" kavramı, Ed Hooks'un oyunculuk tekniklerinden Stanislavski sistemive Leslie Bishko'un LMA yöntemi bu çalışmalar arasında yer almaktadır. Bu çalışmaların odağında genelde animasyon karakterinin iç dünyası ve geliştirilen bu iç dünyaya ait duygu, düşünce ve dürtünün hareket desenlerine aktarııma arayışları olduğu görülmektedir. Bu çalışmalar ve gelişmeler sonucunda günümüz animasyon sineması hareketlendirme sürecinde multi-disipliner bir yaklaşım ile melez bir teknik kullanılmaya başlanmıştır.

John Lasseter, ilk 3 boyutlu animasyon film örneği olarak kabul edilen "Andre ve Wall.B. 'nin Maceraları"nda (The Advantures of Andre and Wall.B.-1986) "kişiselleştirme" (personality) kavramına yer verir. Lasseter, çalışmasında Animasyonun 12 Prensibi'nde karakterin hareket tasarımında duygu ve düşünce aktarımındaki eksikliğin farkına varmış ve her bir prensip ile ayrı ayrı ele alınması gereken "kişiselleştirme" kavramını geliştirmiştir. Lasseter'ın "kişiselleştirme" kavramında, karakterin içsel derinliğini geliştirme ve Animasyonun 12 Prensibinnin uygulanmasında karakterin duygu, düşünce ve dürtülerinin hareket desenleri ile bağlantısını kurma çabaları olduğu görülmektedir. Animasyon karakterin duygularının ve düşüncelerinin seyirciye ulaştırılmasının öne-

6 Animasyonun 21 Temeli (21 Foundation of Animation): Dermot O'Connor tarafından 2018 yılında yayınlanan ve animasyonun 12 prensibini genişleten animasyon temelleridir. Detaylı bilgi için "http://www.angryanimator.com" sayfasını incelyeyiniz (O'Connor, 2018) 
mini vurgulayan oyuncu eğitmeni Ed Hooks, Graham ve Lasseter karakterin kişilik derinliğini kazandırma çabalarını farklı bir noktaya taşımıştır. Hooks tarafından 2000'li yıllarda animasyon sinemasındaki kişiselleştirme sorununa, Stanislavski'nin oyunculuk teknikleri bir çözüm olarak sunulmuştur. Hooks'un animasyon stüdyoları ile yaptığı ortak çalışmalar incelendiğinde, tiyatro ve sinema oyunculuğundaki Stanislavski'nin oyunculuk tekniklerinin animasyon sinemasında uygulanmasına yönelik eğitim programları olduğu görülmektedir. Bu çalışmaların içeriği; karakterin iç dünyasının tasarlanması, kişiselleştirme, karaktere duygusal ve düşünce derinliği kazandırma gibi konulardan oluşmaktadır. Bu maksatla Stanislavski'nin çalışmalarında yer verdiği oyunculuk tekniklerindeki; "coşku belleği", "sihirli eğer", "üstün amaç" gibi başlıklar öne çıkmaktadır (Stanislavski, 2012). Hooks'un yaptığı bu çalışmalarda animasyon karakterinin iç dünyasının yaratıımasını, iç dürtülerinin kurgulanmasını amaçladığı görülebilir. Ancak Stanislavski'nin erken dönem çalışmalarında, oyunculukta karşılaştığı iç dürtüler ile dışsal hareketin ilişkilendirilmesi sorunu animasyon sinemasında da ortaya çıkmaktadır. Bu noktada animasyon karakterinin içten gelen duygu ve düşüncelerinin dışa vuran hareketi ile ilişkilendirmesinde, hareket mekaniğinin tasarlanmasında LMA yönteminin alternatif ve etkili bir çözüm sunduğu düşünülmektedir. Hooks bu bağlamda LMA yönteminin oyunculukta sunduğu çözümün önemine işaret eder ve LMA yönteminin oyuncular ve animasyon sanatçıları için halen tam olarak keşfedilmemiş önemli bir alan olduğunu vurgular (Hooks, 2003, s. 70-75).

LMA yönteminin animasyon sinemasında kullanılması, animasyon sinemasının dans ile ilişkisini öne çıkarmaktadır. Paul Wells, animasyon, dans ve devinim arasındaki ilişkiye işaret eder ve deneysel canlandırma sanatçısı Norman McLaren'in çalışmaları üzerinden açıklar. Wells'e göre McLaren için her animasyon filmi, dansı yansıtır. Çünkü filmdeki en önemli şey devinim ve harekettir (Wells, 1998, s. 111). Modern dansın çıkışı olarak bilinen LMA yöntemi, dansla olan doğrudan ilişkisinin yanında hareket analizi ve tasarımında sunduğu yenilikçi ve analitik çözümler nedeniyle de önem taşımaktadır. LMA yönteminin bu yenilikçi ve analitik çözümlerinin ise animasyon sanatçısı için hareketlendirme noktasında yeni fırsatlar sunduğu kabul edilmektedir. Bu fırsatları animasyon sinemasında kullanma fikrini ilk olarak 1991 yılında Leslie Bishko ortaya atmıştır (Bishko, 1991). Bishko yaptığı çalışmada LMA yönteminin karakter animasyon üretim sürecinde bir yöntem olarak kullanıp kullanılamayacağını tartışmaya açmıştır. Bishko'nun LMA yönteminin animasyon sinemasında kullanılması için yaptığı çalışmalarda özellikle çaba (effort) ve biçim (shape) unsurlarına yer verdiği görülmektedir (Bishko, 2007) (Bishko, 2017). LMA yönteminde çaba, içsel tavrın dışsal hareket üzerinden ifadesi olarak tanımlanır. Biçim kavramı ise hareketin içsel yönü olan dinamosefik hareketin üç boyutlu uzay içerisinde bedeni biçimlendirmesi olarak tanımlanmaktadır. LMA'nın bu yönü ile karakterin iç dünyasında yaratılan duygu, düşünce ve dürtünün dış dünyasını oluşturan hareket desenlerine yansıtılmasında bir yöntem olarak öne çıktığı görülmektedir.

Tüm bu çalışmalar karakterin geliştirilmesi sürecinde, yaşayan bir karakter yaratmak konusunda da yardımcı olmaktadır. Hareketlendirme öncesi senaryo tasarım sürecinde karakter profillerinin oluşturulması maksadıyla çalışmalar yapıldığı bilinmektedir. Bu çalışmalarda karakterin alt yapısı oluşturulurken sosyolojik, psikolojik ve fizyolojik 
özellikleri tasarlanmaktadır (Akyürek, 2004). Bu şekilde karakterin hareket desenlerini etkileyebilecek özellikler önceden belirlenmektedir. Örneğin zayıf bir bedene sahip bir karakterin hareket desenlerinin dinamik bir şekilde tasarlanması gerektiği önceden belirlenmektedir. Benzer şekilde psikolojik olarak saplantıları olan bir karakterin hareket desenlerindeki tutukluk önceden tespit edilebilmekte ya da sosyolojik olarak üst tabakaya ait bir karakterin bu sosyolojik özelliği hareket desenlerinin tasarımlarını etkileyebilmektedir. Bu maksatla karakter tasarım sürecinde tanımlanan sosyolojik, psikolojik ve fizyolojik özellikler göz önünde bulundurularak karakter sayfaları hazırlanmakta, test animasyonları üretilmekte ve animasyon sanatçılarının bilgilendirilmesi amacıyla canlandırılacak karakter için ön hazırlık çalışmaları yapılmaktadır.

Erken dönem ve olgunlaşma döneminden günümüze, seyircinin animasyon sinemasına yaklaşımı ve beklentileri değişmiş ve dönüşmüştür. Seyircinin animasyon sinemasında ağırlıklı olarak yöneldiği karakter ve karakterin oyunculuğu ön plana çıkmıştır. Bu karakterler insan olabildiği gibi antropomorphik karakterler de olabilir. Karakter çeşitliliği anlamında Kung fu Panda (2008), Wall-E (2008), Shrek (2007), Tangled (2010), Incredibles (2004), Ratatuy (2007), Moana (2017) gibi filmler örnek gösterilebilir. Seyircinin animasyon filmlerdeki karakterlere bu denli bağlanması ve empati kurması animasyon karakterlerin tüm bu bahsettiğimiz süreç içerisinde içselliği dışa yansıtma noktasında yakaladığı hareket estetiği ile mümkün olmaktadır. LMA, karakterin iç dünyası ile hareketleri arasında tutarlıı̆ı sağlamada önemli bir yöntem olarak karşımıza çıkmaktadır. Bu noktadan hareketle, bu çalışmada Türk çizgi film (animasyon) sektöründe üretilen çizgi film (animasyon) projelerinde yaratılan karakterlerin hareket tasarımlarının LMA yöntemi kullanılarak incelenmesi amaçlanmaktadır. Bu kapsamda karakterin iç dünyası ile oyunculuk/performans tasarımlarının tutarlılıklarının incelenmesi ve varsa hareketlendirme sürecindeki eksiklerin ortaya konması amaçlanmıştır. Bu çerçevede sevilen Türk çizgi dizi projelerden "Rafadan Tayfa"hın bir bölümünde Hayri karakterinin hareket desenleri LMA yönteminin çaba unsuru üzerinden analiz edilmiş ve değerlendirilmiştir.

\section{Laban Hareket Analizi (LMA) Yöntemi ve Kullanımı}

Laban Hareket Analizi (Laban Movement Analysis-LMA), Rudolf Laban'ın çalışmalarını temel alan Irmgard Bartenieff'in (1900-1981) kurduğu Laban/Bartenieff Enstitüsü (Laban- Bartenieff Institute of Movement Studies) tarafından geliştirilmiş bir hareket analiz yöntemidir. 20 yy. başlarında tiyatro, dans gibi sahne sanatlarında, hareket analizi, hareket tasarımı ve oyunculuk alanında kullanılmıştır. LMA yöntemi, hareketin gözlemlenmesi, tanımlanması, yorumlanması ve kayıt altına alınmasında sunduğu analitik çözümler ile kendinden önceki hareket analiz yöntemlerinden ayrılmakta ve hareket tasarım sürecinde yenilikçi ve geniş kapsamlı çözümler sunmaktadır. $\mathrm{Bu}$ yöntem, hareket ve hareketin kaynağı arasında bağlantı kurulmasına olanak sağlamaktadır. LMA yöntemi, ekspresyonist ve modern dansa katkıda bulunduğu gibi dünya çapındaki hareket çalışmalarına, teorilerine de temel teşkil etmiştir. LMA'nın bu kapsamdaki katkılarını değerlendiren oyuncu eğitmeni Nicole Potter, LMA'nın dans dışında insani hareketlerin çözümlenmesi amacıyla kullanılabilecek geniş kapsamlı bir sistem olduğunu işaret etmektedir (2002, s. 74). LMA, hareket üzerine yapılacak tüm 
çalışmalar için önemli bir kaynak olarak kabul edilmektedir.

LMA yöntemi, Rudolf Laban'ın notasyon sistemi ve dualistik yaklaşımı ile geliştirilen bir dizi kurama dayanmaktadır. Hareket analiz çalışmalarının temelini oluşturan notasyon sistemi bedenin her bir parçasının ayrı ayrı işaretlenmesi ve uzaydaki konumlarının $\mathrm{x}, \mathrm{y}, \mathrm{z}$ koordinat sistemiyle haritalanması prensibine dayanır. Hareketin haritalanması amacıyla kinesifer (kinesphere) adı verilen geometik bir form kullanılır. Laban hareket analiz çalışmalarının temelini oluşturan "Laban'ın Dualistik Yaklaşımı (Laban Dualistik Approach)", hareketin tespit edilen iki uç noktası (hızlanan/yavaşlayan, doğrudan/ dolaylı hareket vb.) üzerinden niceliğinin tanımlanmasına dayanmaktadır. Laban hareket analiz çalışmaları hareketi gözlemleme, tanımlama aşamasında geometri ve üç boyutlu koordinat sistemi ile somut verilere dayalı çözümler sunar. Hareketin yorumlanması aşamasında ise gözlemleme ve tanımlama sürecinde elde edilen somut verileri analiz eder ve bu veriler doğrultusunda analitik, deneye dayalı bir yöntem takip eder. Bu yönteme dayalı geliştirdiği teoriler ile hareket analiz çalışmalarını destekler. Laban'ın geliştirmiş olduğu hareket analiz çalışmaları, kendinden önce yapılan çalışmaları derinleştirerek hareketin kapsamlı bir şekilde ele alınmasına ve hareketin görünmeyen yönü olan duygu, düşünce ve dürtü ile ilişkilendirmesine imkân sağlar.
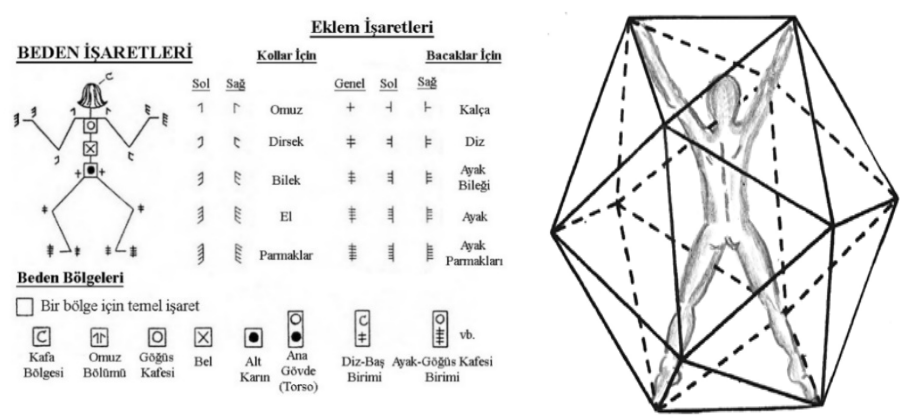

Görsel 1: (Solda) Labanotasyon sisteminde vücut parçalarını temsil eden işaretler (Davies, 2006, s. 10). (Sağda) Laban hareket analiz çalışmlarında kullanılan kinesifer (Moore, 2009, s. $66,118)$

Rudolf Laban, hareket analiz çalışmalarında gözlemlediği ve tanımladığı hareketi iki farklı alanda ele alır. Buna göre hareket gözlemlenebilen kinesifik eylem (kinespheric action) ve gözle görülemeyen dinamosefik hareket (dynamospheric movement) olmak üzere iki farklı alanda gerçekleşir. Laban'a göre kinesifik eylem hareketin üç boyutlu uzayda beden ile gerçekleştirilen ve gözlemlenebilen yönünü temsil eder. Laban çalışmalarında bu hareket türünü iz formları (trace forms) olarak da tanımlar. Dinamosefik hareket ise kinesifik eyleminin dışında kalan, gözlemlenemeyen, fakat eylemi yaratan düşünce, duygu alanını temsil eder. Çalışmalarında dinamosefik hareketi, gölge formlar (shadow forms) olarak da adlandırdığı görülmektedir. Laban, bu iki alandaki hareketleri ilişkilendirmek amacıyla Topolojik Hareket (Topological Movement), Rezervuar Hareketi (Rezervoir Movement) gibi teoriler öne sürer. Laban'ın bu 
iki alandaki hareket türünü ilişkilendirirken kullandığı yöntem, hareketi haritalamakta da kullandığı dualistik yaklaşımdır. Bu yöntem ile Labanotasyon sistemi kullanarak kinesifik eylemde çözümlenen hareket, dinamosefik hareket ile ilişkilendirilir. Rudolf Laban'ın hareket analiz çalışmalarında kullandığı bu yenilikçi yöntem ile hareketin Choreutics, Eukinetic niteliklerini açıklayan yaklaşımlarını/fikirlerini ortaya koyduğu, Harmonik Uzay (Harmonic Space) teorisini geliştirir. Harmonik Uzay teorisini oluşturan kavramlardan Choreutics, hareketin görünen kinesifik eylem yönüyle ilgilenirken, Eukinetic hareketin dinamosefik hareket yönüyle diğer bir ifade ile hareketin görünmeyen yönü ile ilgilenir (Sutil, 2013, s. 176-179) (Davies, 2006, s. 31-37).

Laban'ın hareket analiz çalışmalarında olduğu gibi LMAyönteminde de "uzay"ve "çaba" kavramlarına yer verilir. Uzay, karakterin içinde bulunduğu, hareketin gerçekleştiği üç boyutlu alanın tamamını kapsar. Hareketin gözlemlenebilen yönü olarak kabul edilen kinesifik eyleminin gerçekleştiği alandır. Uzay, hareketin "nerede?" gerçekleştiği ile ilgilidir. Bu özellikleri nedeniyle hareketin dışsal yönü olarak da tanımlanır. Çaba (effort) ise hareketi tetiklediği kabul edilen karakterin düşünce, duygu dünyasını kapsar. Hareketin gözlemlenemeyen yönü olarak kabul edilen dinomasifik hareketin gerçekleştiği alandır. Çaba, hareketin uzay içerisinde "nasıl?" gerçekleştiği ile ilgilidir. Bu özellikleri nedeniyle hareketin içsel yönü olarak da tanımlanır. LMA yöntemi hareketin gözlemlenmesini, tanımlanmasını ve yorumlanmasını çaba ile şekillenen bedenin, uzaydaki üç boyutlu biçimi üzerinden yapar. Bu nedenle çaba ve uzay kavramlarının etrafında geliştirilen LMA yönteminde beden (body) ve biçim (shape) kavramlarına da yer verilir. LMA yöntemine göre çaba niteliği olarak kabul edilen, bir niyet, amaç ya da duygu ile başlayan hareket üç boyutlu uzayda bedenin biçimlenmesi ile tamamlanır (Potter, 2002, s. 73-84); (Newlove, 1993, s. 15-86).

$L M A$, hareketi sosyal ve kültürel kapsamda ele alır, psikofiziksel çerçevede değerlendirir. Bu yönü ile hareketin evrensel çözümlemesinde yaygın şekilde kullanılan bir hareket analiz yöntemi olarak kabul edilir. LMA, beden, çaba, biçim ve uzay'ın birbiri ile sürekli etkileşim içerisinde olduğunu kabul eder.

LMA yönteminde beden, işaretler ile temsil edilen, haritalanan ve analitik veriler doğrultusunda gözlemleme ve tanımlama imkânı sunan asıl kaynak olarak kabul edilir. Aynı zamanda uzay içerisinde yer alan, hareketin gerçekleştiği, içsel duyguların dışarıya açıldığı bir kapı olarak da tanımlanır. Bu yönü ile bedenin, oyuncu tarafından kurgulanan, tasarlanan, geliştirilen karakter ve bu karaktere ait hareket tasarımlarını icra eden bir araç olduğu söylenebilir.

LMA yönteminde uzay, içsel dürtüler ile tetiklenen veya tasarlanan hareketin, beden aracılığıyla gerçekleştiği alan, diğer bir ifadeyle hareketin iz formlarının gözlemlendiği üç boyutlu hacim, mekân olarak tanımlanmaktadır. Rudolf Laban uzayı, geniş ve dar kapsamlı olmak üzere iki farklı şekilde değerlendirir. Uzayın, geniş kapsamlı değerlendirmesinde, bedenin sahne içerisinde takip ettiği rota ele alınır. Dar kapsamlı değerlendirmesinde ise bu rota boyunca bedeni ve onun uzuvlarını kapladığı kabul edilen baloncuk, diğer bir adıyla kinesifer içerisinde gerçekleşen hareketleri ele alır.

LMA yönteminde biçim, Rudolf Laban'ın erken dönem çalışmalarında yer almamakla birlikte yönetici danışmanı Warren Lamb ile yaptığı çalışmalar sonrasında ayrı bir başlık 
olarak değerlendirilmeye başlanmıştır. LMA siteminde biçim kavramı, hareketin içsel yönü olan dinamosefik hareketin üç boyutlu uzay içerisinde bedeni biçimlendirmesi olarak tanımlanmaktadır. Diğer bir ifade ile içsel dünyadaki niyet, dürtü, duygunun biçimlendirdiği bedenin gözlemlenebilen geometrik şeklidir. Bu kapsamda biçim; beden ve uzayı ilişkilendirir, aralarında karşılıklı bağlantı kurar ve bir köprü görevi üstlenir. Biçimi oluşturan bu uyarlanma veya şekillenme süreci vücudun bütünüyle ya da sadece tek bir parçasıyla icra edilebilir. Çabanın uygulanmasına benzer şekilde biçim; "ne?, nerede?, ne zaman?, nasıl?" soruları ile değerlendirilir. Bu değerlendirme sonucunda seçilen biçim kalıpları (shape forms), biçim değiştirme yöntemleri (modes of shape changes) karakterin duygu, düşünce, ruh hali veya tavrının etkili bir şekilde izleyiciye aktarılmasına hizmet eder (Potter, 2002, s. 77-80); (Bishko, 2014, s. 195-196).

LMA yönteminde çaba, içsel tavrın dışsal hareket üzerinden ifadesi olarak tanımlanır. Diğer bir ifadeyle gözlemlenemeyen dinamosefik hareketin gözlemlenebilen kinesifik eylem üzerinden tanımlanması ve yorumlanmasıdır. Bartenieff, LMA yönteminde hareketin gölge formları ve iz formları arasındaki ilişkiyi kurmak amacıyla çaba faktörlerini (effort foctors) kullanır. Bu amaçla kullanılan çaba faktörleri; uzay (space), zaman (time), ağırlık (weight) ve akış (flow) olmak üzere dört başlıkta incelenir. Hareketin, dualistik sistem ile ele alınarak kendini oluşturan iki uç nokta üzerinden incelenmesi kutuplu (polar) sistem olarak da adlandırılır. Kutuplu sistem ile tespit edilen hareketin iki uç noktası o hareketin çaba niteliklerini oluşturur. LMA'nın dört çaba faktörü ve onları oluşturan zıt çaba nitelikleri aşağıdaki gibidir (Moore, 2009, s. 150-153); (Bishko, 2014, s. 178-195); (Potter, 2002, s. 74-75);
Uzay : Doğrusal (direct)-Dolaylı (indirect),
Zaman : Hızlanan (accelerating)- Yavaşlayan (decelerating),
Ağırlık : : Artan baskı (increasing pressure)- Azalan baskı (decreasing pressure),

Akış : : Bağlayıcı (binding) - Serbest (freeing).

\subsection{Uzay}

Hareketin "nerede?" olduğu ile ilgili olan uzay çaba faktörü, Laban'ın dualistik yaklaşımında doğrudana karşılık dolaylı çaba niteliği olmak üzere iki uç hareket ile tanımlanır. Mekânsal yönlendirme olarak da ifade edilir. Laban tarafından hareketin düşünce unsurunu temsil ettiği kabul edilir. Dualistik yapı içerisinde her iki uzay çaba niteliği değerlendirildiğinde; doğrudan çaba niteliği tek yönde, tek doğrultuda, bir amaç içeren hareket desenleri olarak gözlemlenirken, dolaylı çaba niteliği mekânın farklı yönlerinde değişen, sürekli hareket desenleri olarak gözlemlenebilir. Örneğin; bir hedefe ulaşmak, çivi çakmak doğrudan uzay çaba niteliğine örnek gösterilebilir. Zemine düşürülen kontak lens, iğne vb. bir objeyi arama eylemi ise dolaylı uzay çaba niteliğine örnek gösterilebilir. Uzay çaba faktörü üzerinde yapılacak tercihler, değişiklikler aracılığıyla bedenin mekân içerisindeki pozisyonu veya rotası üzerinde düzenlemeler yapılabilir ve hareketin uzay içerisindeki konumu hassas bir şekilde ayarlanabilir. 


\subsection{Zaman}

Hareketin "ne zaman?" ve "ne şiddetle?" yapılacağı ile ilgili olan zaman çaba faktörü, Laban'ın dualistik yaklaşımında hızlanana karşılık yavaşlayan çaba niteliği olmak üzere iki uç hareket ile tanımlanır. Hareketin hızının artırıması ya da yavaşlatılması olarak da ifade edilebilir. Laban tarafından hareketin sezgi unsurunu temsil ettiği kabul edilir. Hızlanan zaman çaba niteliği ile sıkıştırılan hareket, enerjik, çabuk, şaşırtıcı, acil eylem duygusu yaratabilir. Buna karşılık yavaşlayan zaman çaba niteliği ile hızı düşürülen hareket zaman içerisine yayılabilir. Bu hareket deseni ile gerçekleştirilen eylemin sakin, keyifli olduğu duygusu yaratılabilir. Örneğin, günlük yaşamda bir annenin çocuğunun saçını okşaması, bir ormanda gezinmek yavaşlayan zaman çaba niteliğine örnek gösterilebilir. Bir çekilişte büyük ödülü kazanan kişinin o anda yukarı doğru hızla sıçraması ise hızlanan zaman çaba niteliğine örnek gösterilebilir. Dualistik yapı içerisinde her iki uzay çaba niteliği değerlendirildiğinde, yavaşlayan zaman çaba niteliği bir hedeften diğerine sürekli, durmadan ilerleyen, ya da yavaşlayan, birbirini takip eden hareket desenleri olarak gözlemlenirken, hızlanan zaman çaba niteliği iki hedef arasında ani sıçramalar ile atılan, ilerleyen hareket desenleri olarak gözlemlenebilir. Hareketin zaman çaba faktöründe yapılacak tercihler ve değişiklikler ile farklı hareket desenlerinde telaşlı aceleci veya sakin, ağırbaşlı tavırların hissedilmesi sağlanabilir.

\subsection{Akıs}

Hareketi oluşturan duygunun veya ilerlemenin "nasıl ?" olduğu ile ilgili olan akış çaba faktörü, Laban'ın dualistik yaklaşımında bağlayıcıya karşılık serbest çaba niteliği olmak üzere iki uç hareket ile tanımlanır. Laban tarafından hareketin duygu unsurunu temsil ettiği kabul edilir. Hissetme, duygu ve hareketin devamlılığı ile ilişkilendirilen akış çaba faktörü, hareketin nasıl ilerlediğinin hissedilmesi olarak özetlenebilir. Bağlayıcı çaba niteliği ile aniden durdurulabilen, herhangi bir anda kesintiye uğrayabilen hareket deseni ifade edilmekte ve akışa direnen her an durmaya hazır, hassas, kontrollü, içsel enerjinin hapsedildiği hareket kalıpları olarak tanımlanmaktadır. Buna karşılık serbest akış çaba niteliği ile aniden durdurulması güç olan, sürekli, devamlı hareket deseni ifade edilmekte ve akışa bırakılmış, kontrolsüz, dışsal enerjinin serbest bırakıldığı, durdurulamaz hareket kalıpları olarak tanımlanmaktadır. Serbest akış çaba niteliğin aynı zamanda harici enerjinin serbest bırakılması olarak da yorumlanır. Çoğunlukla bir hareket deseninin hazırlık aşaması bağlı akış çaba niteliği olarak değerlendirilmektedir. Örneğin günlük yaşamda Jenga oyununda bir tahta parçasını sütunun içinden çekme eylemi bağlı çaba niteliğine örnek gösterilebilir. Tahta bloğu sütundan çıkardıktan sonraki eylem ise serbest çaba niteliğine örnek gösterilebilir. Hareketin akış çaba faktöründe yapılacak tercihler ve değişiklikler ile farklı hareket desenlerinde sürekli, akışkan değişimlerin yakalanması ve hareketin nasıl ilerlediğinin hissedilmesi sağlanabilir.

\subsection{Ağırlık}

Hareketin "ne?" olduğu ile ilgili olan ağırlık çaba faktörü Laban'ın dualistik yaklaşımında artan baskıya karşııı azalan baskı çaba niteliği olmak üzere iki uç hareket ile tanımlanır. 
Bedenin yerçekimine karşı koyarken, kaslarda oluşan gerginlik ya da gevşeme şeklinde açıklanmaktadır. Laban tarafından hareketin algılanma şeklini temsil ettiği kabul edilir. Diğer bir ifade ile yerçekiminin nasıl hissedildiği, yerçekimi ile nasıl mücadele edildiği ya da karakterin yerçekimine bağlı olarak kütlesini ayarlanması şeklinde de özetlenebilir. Laban, artan baskı ağırlık çaba niteliği ile elde edilen hareket desenlerinin sağlam ve güçlü görüneceğini savunur. Buna karşııı azalan baskı ağırlık çaba niteliği ile bedendeki kasların gevşemesi sonucunda yüzen hareket deseninin yaratılacağını savunur. Hareketin ağırlık çaba niteliğinde yapılacak tercihler ve değişiklikler ile ifadeli eylemlerde güçlü ya da hafif vurgu yapılması sağlanabilir.

Hooks, ilk olarak Bertenieff tarafından yapılan çalışmalarda (Laban'ın çalışmalarının İngiliz versiyonundan farklı olarak) ağırlığı iki ayrı başlık altında ele alındığına yer verir. Buna göre Berteieff, ağırığı aktif ağırlık (active weight) ve pasif ağırlık (passive weight) olarak sınıflandırır. Hooks, Bertanief'in karakterin harekete direnmesi ya da teslim olmasını incelemesi sonucunda ağırlığı aktif ya da pasif olarak sınıflandırdığını işaret eder (Hooks, 2003, p. 72). Diğer bir ifade ile aktif ağırlık, kuvvetin farklı derecelerde bilinçli olarak kullanılması, pasif ağırlık ise yerçekimine teslim olma hali olarak tanımlanabilir. Laban'ın dualistik yaklaşımında aktif ağırık, zayıf ve güç/ü olmak üzere iki çaba niteliğinde, pasif ağırlık ise gevşek (limp) ve ağır (heavy) olmak üzere iki çaba niteliğinde değerlendirilir. Her iki aktif ağırlık çaba niteliği de gücün, ağırlığın hassas ve kuvvetli kullanıldığı hareket desenleri olarak gözlemlenebilir. Örneğin, günlük yaşamda içinde kaynar su dolu olan bir tencereyi yavaşça kaldırmak aktif ağırlık kullanımından zayıf ağırık çaba niteliğine örnek gösterilebilir. Bir masaya hızlı bir şekilde yumruğu vurmak ise aktif ağırlık kullanımından güçlü ağırlık çaba niteliğine örnek gösterilebilir. Hasta, enerjisi tükenen birisinin yerçekimine karşı mücadele ederken gerçekleştirdiği (yürüme, bir yere uzanma) hareket desenleri pasif ağırlık kullanımından gevşek ağırlık çaba niteliğine örnek gösterilebilir. Yatağa veya yere yığılma hareket desenleri ise pasif ağırlık kullanımından ağır ağırlık çaba niteliğine örnek gösterilebilir.

LMA'yı oluşturan beden, uzay, biçim ve çaba unsurları oyunculukta gerek hareket analizi, gerekse hareket tasarımı noktasında geniş bir bakış açısı geliştirilmesine katkı sağlamaktadır. LMA unsurları, özellikle hareketin içsel yönü olarak tanımlanan dinamosefik hareket ile hareketin dışsal yönü olan kinesefik eylem arasındaki bağlantıyı analitik bir çerçevede geometrik formlar içerisinde somutlaştırılmasında, beden-duygu/ düşünce arasındaki bağlantının kurulmasında bir yöntem sunmaktadır.

\section{LMA Yönteminin Animasyon Sinemasında Kullanımı}

LMA yöntemi dans, tiyatro, sinema oyunculuğu ve farklı disiplinlerin yanında son yıllarda animasyon sinemasında da sıklıkla kullanılmaya başlanmıştır. LMA'nın animasyon sinemasında kullanımına ilk yer veren Leslie Bishko yaptığı çalışmalarda, animasyon sineması karakterinin hareketleri ile seyirciye aktarılmak istenen duygu, düşünce arasında tutarlıığın sağlanmasını amaçlar. Bu amaçla yaptığı çalışmalarda LMA yönteminde yer verilen uzay-mekân içerisinde gerçekleşen hareketin, içten gelen dürtüler-duygular ile ilişkilendirilerek tasarlanmasını hedeflemektedir. Bishko'un tartışmaya açtığı LMA'nın animasyon sinemasında kullanımının, kendisinden sonra 
yapılan çalışmalarda farklı şekillerde de ele alındığı görülmektedir. Örneğin animasyon sanatçıları Angie Jones ve Jamie Oliff, LMA yöntemini mekân ve karakter ilişkisinin geliştirilmesi bakımından ele alırlar. Jones ve Oliff'e göre, animasyon sanatçısının karakterin içinde bulunduğu mekânda nasıl hareket edebileceğini, bu mekânı nasıl kullanabileceğini keşfederken oyunculuk tekniklerinin faydalı olabileceğini ve bu kapsamda $L M A$ yönteminin kullanılmasının animasyon sinemasına katkılarını vurgularlar (Jones \& Oliff, 2007, s. 185). Animasyon sineması kuramcısı Paul Wells ise LMA yöntemini, animasyon sinemasında hareketin tasarlanma sürecinde koreografinin kullanılması bakımından değerlendirir ve hareketin koreografik gelişimine katkılarını işaret eder. Wells, Laban'ın teorilerinden "Chourestic" sayesinde animasyon sineması karakterinin; beden bilinci, bedenin ağırlık ve zamana direnci, uzay bilinci, beden uzuvlarının enstrümantal kullanımı, tasarlanan hareketin içerisindeki dürtülerin ve hareketin kaynağının ayırt edilmesi vb. konulardaki katkılarını savunur (1998, s. 111113). John ${ }^{7}$ ve Kristin ${ }^{8}$ Kundert-Gibbs ise $L M A$ yönteminde ki çaba unsurunun önemini vurgularlar. Gibbs ve Gibbs'e göre; “...(Laban) çalışmalarında, oyuncu ve animasyon sanatçıları için en doğrudan uygulanan unsur; ağırlığı, uzayı ve tempo/ritmi inceleyerek bir hareketin niyet ve niteliğini analiz eden çabaya odaklanır. (2009, s. 203)". Gibbs ve Gibbs çaba unsurlarının animasyon sinemasında karakterin iç dünyasının tasarlanması, farklı karakterlerin yaratılması ve hareket tasarımların geliştirilmesi amacıyla bir yöntem olarak kullanılabileceğini savunurlar. LMA üzerine yapılan bu çalışmalarda sahnenin kullanımından, karakterin benden bilicinin geliştirilmesi ve ritmik hareket desenlerinin oluşturulmasına, karakterin tasarlanan iç dünyasının hareket desenlerine yansıtılmasına kadar birçok katkısına yer verilmektedir. Bunlardan LMA yönteminin çaba unsuru ise içsel dünya ile dışsal eylem arasında bağlantı kurması nedeniyle diğer unsurlardan (beden, biçim ve uzay) ayrılmakta ve animasyon sinemasında da kullanılmaktadır. LMA yönteminin çaba unsurunu oluşturan uzay, zaman, akış ve ağırlık faktörlerine diğer disiplinlerde olduğu gibi animasyon sinemasında da yer verilmektedir.

Örneğin, 3 boyutlu bilgisayar animasyon filmi olan "Kung Fu Panda”nın (2008) bir sahnesinde (Görsel 2.1) filmin ana karakteri olan Pu, babasının ona verdiği görevi yerine getirmek amacıyla Yeşim Sarayı'nın merdivenlerini çıkmaya çalışmaktadır (00:09:10). $\mathrm{Pu}$, bu sahnede elindeki nuddle arabasını zorlukla yukarı çekerken bedeni ve fiziksel kabiliyetleri nedeniyle zorlanmaktadır. Pu'nun bu sahnedeki hareket deseni iki farklı bölümde ele alınabilir. Hareketin ilk bölümünde yoğun bir çaba içerisinde nuddle arabasını çekmekte ve yer çekimine karşı bir mücadele verdiği görülmektedir. Hareketin ikinci bölümünde ise tüm çabalarına rağmen enerjisi tükenmekte ve merdivenlere yığılmaktadır. Pu'nun bu sahnedeki hareket deseni LMA yönteminin ağırlık çaba niteliği kapsamında değerlendirildiğinde, ilk bölümde aktif ağırlıkta güç/ü ağırlık çaba niteliğini kullandığı, hareketin ikinci bölümünde ise pasif ağırlıkta ağır ağırlık çaba niteliğini kullandığı söylenebilir. Karakterin iç dünyasında verdiği Yeşim Sarayı'na çıkma savaşı ve sonrasında başarısızlık kaynaklı hüsran olmak üzere iki uç duygunun tasarlanan

7 Doç.(Assoc.Prof.) Johng Kundert-Gibbs: Ohio Devlet Üniversitesi, Çalışma ve uzmanlık alanı; 3 boyutlu modelleme ve animasyon, dramatik yazı, ses tasarımı, Mo-Cap, Modern drama uzmanı.

8 Doç.(Assoc.Prof.) Kristin Kundert-Gibbs: Ohio Devlet Üniversitesi, Lisans koordinatörü. Çalışma ve uzmanlık alanı; Oyunculukta ses tonu, Oyunculuk, Yönetmenlik, Sahne hareketleri. 
hareket desenlerine yansıtılı̆̆ı ve bu şekilde seyirciye aktarılmaya çalışıldığı görülmektedir. Bu örnekteki hareket tasarımında aktif ve pasif ağırlığın art arda kullanımı ile karakterin iç dünyasındaki çatışma ve bu çatışmanın sonucu birlikte verilmektedir.
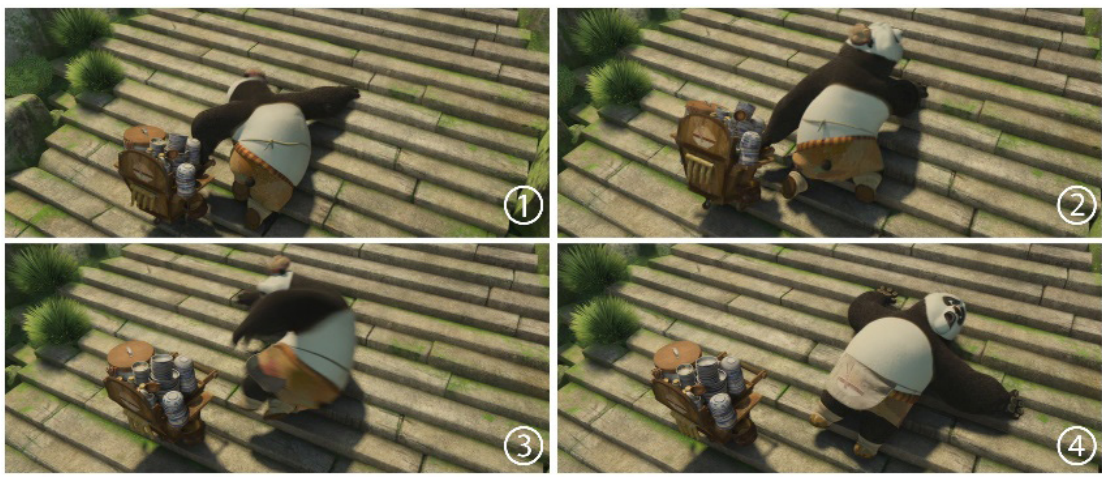

Görsel 2: LMA yöntemi ağırlık çaba faktöründe aktif ağırlık çaba niteliklerinin ve pasif ağırlık çaba niteliklerinin birlikte kullanımı (Osborne \& Steveson, 2008)

Animasyon sinemasında çaba faktörlerinin tek tek kullanımıyla oluşan unsurlar ve farklı birleşimleri ile oluşan durumların, sürücülerin, tamamlanmış sürücülerinin kullanımına oyunculuktakine benzer şekilde yer verilmektedir. Çaba faktörlerinin bir araya gelmesi ile oluşan hareket desenleri belirli özellikler taşımakta, belirli bağlantılar ve ilişkiler doğrultusunda kullanılmaktadır. Moore çaba faktörleri ve duygu arasındaki bu bağlantıyı ve ilişkileri şu şekilde ifade eder "Akış, ağırlık, zaman ve uzay olmak üzere dört hareket faktörü ve sekiz çelişik çaba niteliği, Laban'ın hareketin ruh halinin sınıflandırılmasında geliştirildiği temel unsurlardır (2009, s. 152)". LMA yönteminin oyunculuk eğitiminde kullanılan bu bağlantılarına ve ilişkilerine animasyon sinemasında yer verilmektedir.

Animasyon sinemasında 1900'li yılların başından itibaren dünyada bu gelişmeler yaşanırken Türkiye'de 1950'li yıllarda ilk animasyon sineması denemeleri (Evvel Zaman liçinde-1951) görülmektedir. Türkiye'de, 1990 sonrasındaki dönemde "Bay Yanlış ile Doğru Ahmet" ve "Az Gittik Uz Gittik" gibi kamu spotu ve belgesellerde animasyon örnekleri görülse de 2000'li yıllar sonrasında animasyon sinemasında hızlı bir ilerlemenin olduğu söylenebilir. Bu dönemde reklam sektöründe animasyon örnekleri yoğun bir şekilde kullanılmaya başlanmış ve 2008 yılında TRT Çocuk kanalının kurulması ile TV serisi ve uzun metraj animasyon filmleri ortaya çıkmıştır. Pepe, Cille, Keloğlan, Maysa ile Bulut, Ege ile Gaga, Rafadan Tayfa gibi TV serilerinin yanında Evliya Çelebi: Ölümsüzlük Suyu(2014), Kötü Kedi Şerafettin (2016), Fırıldak Ailesi (2017), Rafadan Tayfa: Dehliz Macerası (2018) gibi uzun metraj animasyon sineması örnekleri de bu dönemde üretilmiştir. Dünyadaki örneklere benzer şekilde Türkiye'de üretilen animasyon sinemasında da stopmotion, cut-out, limited animasyon, 3d bilgisayar animasyonu gibi farklı üretim teknikleri kullanılmaktadır. Türk animasyon sektöründe üretilen animasyon sinemasının son dönem örnekleri hareket tasarımları kapsamında ele alındığında geleneksel animasyon üretim tekniği olarak da bilinen Disney'in Animasy- 
onun 12 Prensibi’nin temel animasyon üretim tekniği olarak kullanıldığı söylenebilir.

Ayrıca Türkiye'de eğitim veren animasyon bölümleri, lisans seviyesindeki öğrencilere eğitimlerinde animasyonun 12 Prensibi, Animasyonun Elemanları gibi kavramlarla karakter animasyonu eğitimi vermektedir. Bunun yanında Stanislavski Sistemi gibi multi disipliner çalışmalara da yer verilmektedir. Ancak ne eğitim alanında ne de Türk animasyon sektöründe üretilen film örneklerinde karakter animasyonunda ve hareket tasarımında LMA yönteminin henüz kullanılmadığı görülmektedir.

2000’li yıllar sonrasında Türk çizgi film (animasyon) sektöründe üretilen projelerde seyirci ile iletişim kurmada ve empatinin sağlanmasında zorluklar yaşandığı söylenebilir. Bunun en büyük göstergesi seyircinin animasyon karakterlerle özdeşleşme sorunudur. Seyircinin animasyon filmlerdeki karakterlerle bağlantı ve empati kurması animasyon karakterlerin içselliğini dışa yansıtma noktasında yakaladığı hareket estetiği ile mümkün olmaktadır. Türkiye'de üretilen bu projelerde hareketlendirme sürecinin karmaşıklığının bir sonucu olarak (küresel çaptaki örneklere benzer şekilde) yaratılan karakterin iç dünyası ve hareket tasarımları arasında ilişkinin kurulmasında zorluklar yaşanması seyircinin karakterle özdeşleşmesini engellemektedir. Bu noktada LMA yöntemi, estetik hareket tasarımlarının yaratılmasında çözümler sunmaktadır. Bu noktadan hareketle, bu çalışmada Türk animasyon (çizgi film) sektöründe üretilen projelerde yaratılan karakterlerin hareket tasarımlarının LMA yöntemi kullanılarak incelenmesi amaçlanmaktadır. Bu kapsamda karakterin iç dünyası ile oyunculuk/performans tasarımlarının tutarlılıklarının incelenmesi ve varsa hareketlendirme sürecindeki eksiklerin ortaya konması amaçlanmıştır.

\section{Yöntem}

Bu çalışmada sevilen Türk çizgi dizi projelerden "Rafadan Tayfa"nın seçilen bir bölümünde Hayri karakterinin hareket desenleri LMA yönteminin çaba unsuru üzerinden analiz edilmiştir. Bu amaçla "Rafadan Tayfa"TV çizgi dizi serisinin Hayri karakterinin LMA yönteminin çaba unsurunu oluşturan aşağıdaki faktörler kullanılarak hareket analizleri yapılmıştır:

- Uzay: karakterin sahne içerisinde kendisini çevreleyen uzay kullanım şekli,

- Zaman: karakterin tasarlanan hareketi gerçekleştirme sürecindeki zaman kullanımı,

- Ağırlık: karakterin kütlesinin hissettirilmesi,

- Akış: hareket desenlerin durdurulabilir ya da durdurulamaz nitelikte kullanımı.

$\mathrm{Bu}$ çaba faktörleri Hayri karakterinin senaryoya bağlı olarak sahne içerisinde gerçekleştirdiği hareketi ile bu hareketi oluşturan duygu-düşünce-dürtü arasında kurulan ilişkiyi ortaya koyacak şekilde incelenmesi ve yorumlanmasında kullanılmıştır. Gerçekleştirilen hareket analizleri aşağıdaki sorular kapsamında değerlendirilmiştir;

- Hayri karakterinin hareket desenlerinde LMA yöntemi uzay, zaman, ağırlık ve akış çaba faktörlerinin kullanılıp kullanılmadığı,

- Uzay, zaman, ağırlık ve akış çaba faktörleri kullanıldıysa iç dünyasını oluşturan duygu ve düşünlerini destekler nitelikte olup olmadığı, 
- Karakterin hareket estetiğinde yenilikçi uygulamalar getirip getirmediği sorularına yanıt aranmıştır.

\section{Bulgular ve Yorum}

\subsection{LMA Yöntemi İle "Rafadan Tayfa” TV Çizgi Dizisinde Hareket Analizi}

Bu çalışmada LMA yöntemi kullanılarak, TRT Çocuk kanalında yayınlanan "Rafadan Tayfa"(ISF Stüdyos-2014) TV çizgi dizisinin seçilen bir bölümünde bir karakterin hareket analizi gerçekleştirilmiştir. 85 bölüm yayınlanan dizinin, youtube kanalında 6.538.358 kez izlenen ve 14.000 beğeni alan "Rafadan Rafadana Karşı (12dk.)" bölümü LMA yöntemi ile hareket analizi için seçilmiştir (http-1).

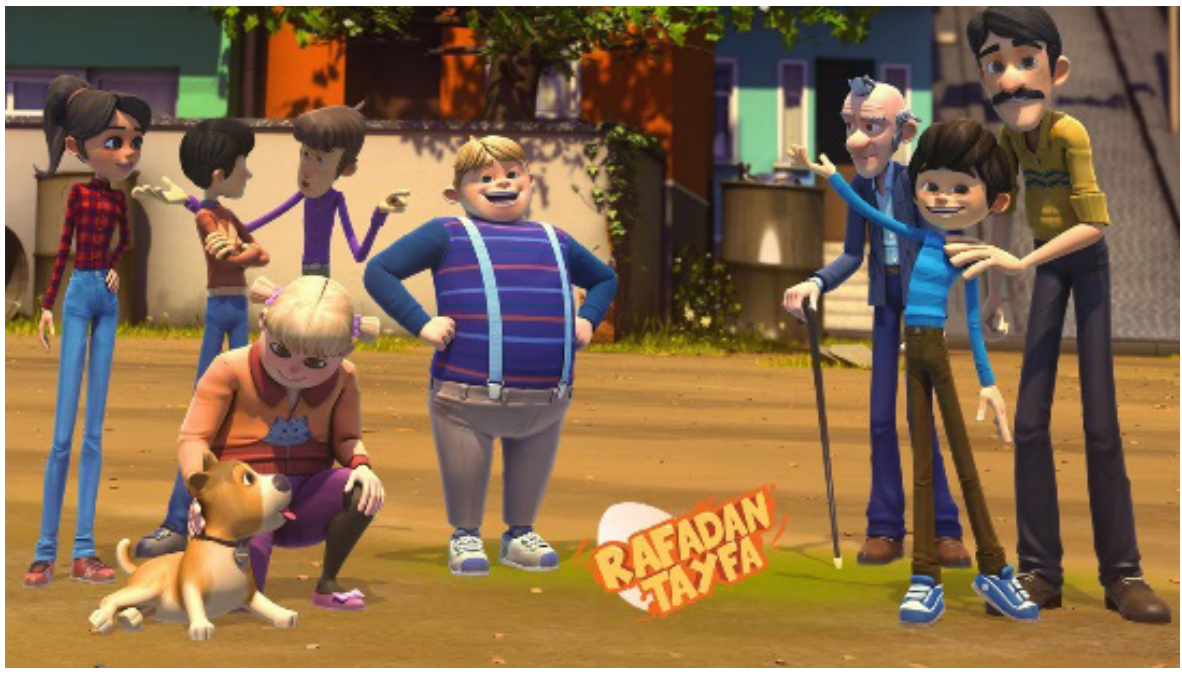

Görsel 3: Rafadan Tayfa TV çizgi dizi serisi ana karakterleri; Sevim, Mert, Kamil, Hale, Hayri, Basri Amca, Akın, Rüstem abi ve köpekleri Yumak (http-2).

"Rafadan Tayfa" TV çizgi dizi serisi İstanbul'da bir mahallede yaşayan 9-12 yaşları arasındaki dört kafadar arkadaşın her bölümde yeni bir maceraya atılmasını konu almaktadır. Projede, Türkiye'nin 1980-1990 yıllarındaki mahalle atmosferinin ve bu mahallelerdeki insan ilişkilerinin ele alındığı görülmektedir. Aynı mahallede yaşayan dört kafadar Mert, Hayri, Akın ve Kamil projenin ana karakterleridir. Bu karakterlerden Hayri diğerleri ile sürekli çatışması ve fiziksel özellikleri bakımından uç örneği temsil etmesi nedeniyle diğer karakterlerden ayrılmaktadır. Bu nedenle hareket analizleri yapılması amacıyla Hayri karakteri seçilmiştir. "Rafadan Rafadan'a Karşı" bölümündeki Hayri'nin hareket tasarımları LMA yöntemi çaba unsuru kapsamında değerlendirilmiştir. $\mathrm{Bu}$ amaçla karakterin iç dünyasını oluşturan ana duygular ve dürtüler tespit edilerek hareket desenleri ile tutarlılığı uzay, zaman, ağırlık ve akış çaba faktörleri üzerinden analiz edilmiştir. Diğer karakterlerin LMA yöntemine göre genel hareket analizlerine sonuç bölümünde yer verilmiştir. 


\subsubsection{Hayri karakterinin hareket analizi}

LMA yöntemi çaba unsuru kapsamında hareket analizi yapılmak amacıyla seçilen karakterlerden Hayri, diğer karakterler arasında oburluk derecesinde yemeğe olan düşkünlüğü ile öne çıkmaktadır. Ayrıca grubun en şişman üyesidir. Onun yemeğe olan düşkünlüğü başlarına gelen olayların akışını değiştirecek seviyededir. Rafadan Tayfa grubun isim babasıdır. Diğer grup üyeleri ile (özellikle Kamil ile) sürekli bir inatlaşma halindedir. Projede yer alan diğer karakterler gibi o da sürekli bir telaş içerisindedir. Olayları abartması onun temel özelliklerindendir.

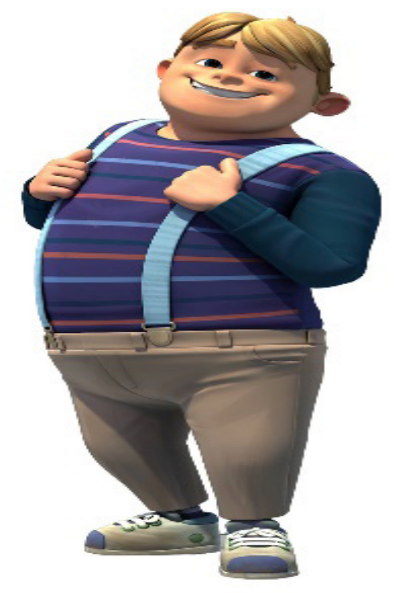

Görsel 4: "Rafadan Tayfa" çizgi dizi ana karakterlerinden Hayri (http-3)

Hayri'nin seri genelindeki hareket desenleri incelendiğinde sürekli muziplik peşinde koşuşturan neşeli bir karakter olduğu görülmektedir. Bununla birlikte grup arkadaşları ile ilişkilerinde bencil bir tavır sergilediği görülmektedir. Zaman zaman bu tavrı arkadaşlarının haklarını hiçe sayma şeklindedir. Diğer grup üyeleri ile çatışmalarının çoğu bu bencil tavırlarından kaynaklanmaktadır. Hayri'nin iç dünyasını kaplayan ana duygunun neşe olduğu, ana dürtünün ise karnını doyurmak olduğu görülmektedir.

\subsubsection{Uzay}

Hayri'nin hareket desenleri LMA yöntemi uzay çaba faktörü kapsamında incelendiğinde dolaylı uzay çaba niteliğinin yoğun bir şekilde kullandığı görülmektedir. Ancak bazı hareket desenlerinde dolaylı ve doğrudan uzay çaba niteliği birlikte kullanılmaktadır. Hareket desenlerinde dolaylı zaman çaba niteliği kullanılırken ufak poz değişimlerinin kullanıldığı, doğrudan uzay çaba niteliğinde ise büyük poz değişimlerinin kullanıldığı görülmektedir. Ancak Hayri'nin hareket desenlerinin geneli incelendiğinde dolaylı uzay çaba niteliğinin kullanımının yoğun olduğu söylenebilir. Hayri'nin hareket desenlerindeki dolaylı uzay çaba niteliği kullanımında, iç dünyasını kaplayan duygu ve düşünceyi desteklenmediği durumlara rastlanmaktadır. Örneğin Hayri, Kamil ve Mert'in aşağı mahallede basket oynayan diğer grup ile karşılaştıkları sahnede (05:29) Hayri, Mert'e 
basket oynayan grubun tanıdık geldiğini söylerken bir dizi hareket deseni sergiler (Bakınız Görsel 4-3).
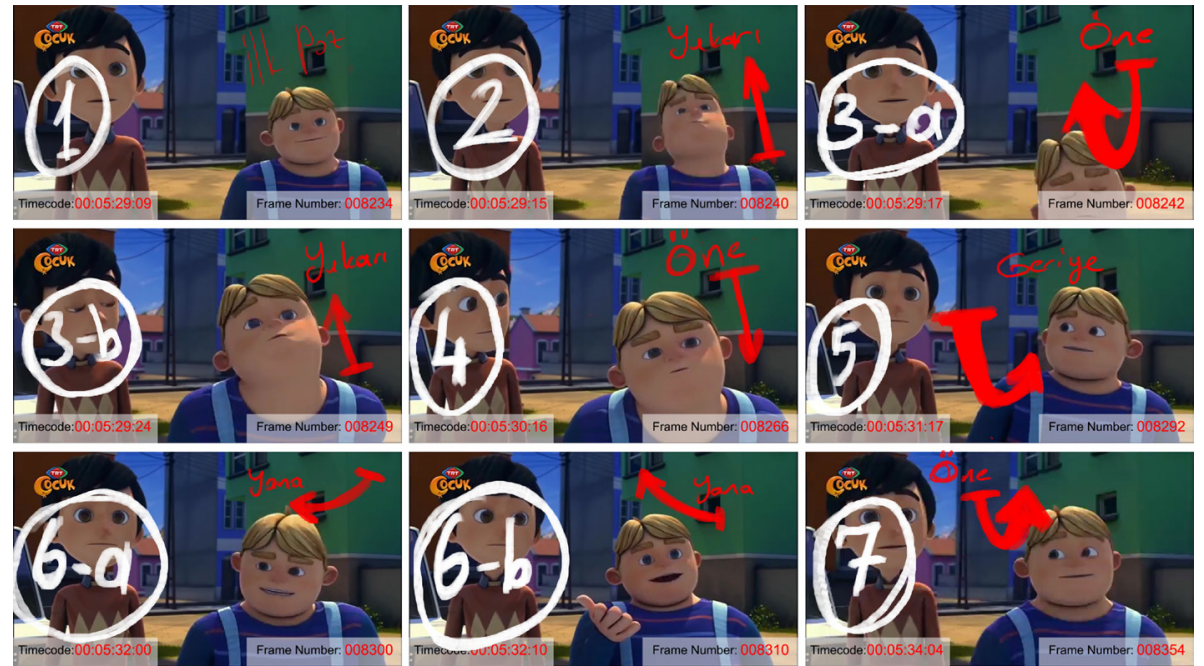

Görsel 5: Hayri'nin hareket desenlerinde uç poz tasarımında dolaylı uzay çaba niteliğinin kullanımı (Yasin Arslan kişisel arşivi)

Bu sahnede, normal konuşma ritminde basket oynayan çocukların tanıdık geldiğini söylerken Hayri'nin iç dünyasına hâkim bir duygu yoktur. Ses tonundan anlaşıldığı kadarıyla Hayri'nin iç dünyasına sakin bir duygu durumu hâkimdir. Hayri'nin odağında ise karşısında basket oynayan çocuklar vardır. Ancak Hayri beş saniye içerisinde yukarı, aşağı, öne ve arkaya olmak üzere yedi uç pozda altı faklı yöne hareket etmektedir. Dolayısıyla Hayri konuşmasından da anlaşılan odak noktasına yönelmeden önce ve sonra farklı noktalara yönelerek dolaylı uzay çaba niteliğini sergilemektedir. Bu şekilde hedefine dolaylı bir rota kullanarak yönelmekte ve sonrasında ilk pozuna yakın bir poza geri dönmektedir. Hayri'nin buna benzer dolaylı uzay çaba niteliği kullanımına hareket desenlerinin genelinde rastlanmaktadır. Hayri'nin hareket desenlerinde yapılan bu uzay çaba niteliği tercihi iç dünyasını oluşturan asıl odak düşüncenin desteklenmesini engellemektedir. Bu sahnede Hayri kendisini harekete geçiren karşısındaki olaydan çok çevresiyle etkileşime geçmektedir. Hayri'nin hareket desenlerinde kullanılan bu uzay çaba niteliği, iç dünyasında kendisini harekete geçiren düşünceyi destekler nitelikte değildir. Bu sahnedeki hareket deseninde yalnızca doğrudan uzay çaba niteliğinin kullanımının veya fazladan kullanılan beş farklı uç pozun azaltılmasının tutarlı bir hareket deseni ortaya koyacağı söylenebilir.

\subsubsection{Zaman}

Hayri'nin hareket desenleri LMA yöntemi zaman çaba faktörü kapsamında incelendiğinde hızlanan zaman çaba niteliğinin yoğun bir şekilde kullandığı görülmektedir. Hayri'nin hareket tasarımlarının genelinde kullanılan hızlanan zaman çaba niteliğinin iç dünyasını kaplayan duygu ve düşünceyi desteklemediği durumlara rastlanmaktadır. Örneğin Hayri, Kamil ve Mert'in basket oynadığı sahnede (03:20) 
Hayri, Kamil'in attığı baskete Akın'ın sahaya girmesinden dolayı itiraz eder. Bu itiraz sahnesinde önce öfkelenen Hayri daha sonra şaşkınlık ve üzüntü duygularını arka arkaya yaşamaktadır. Bu hareket deseni üç farklı duygunun art arda sergilendiği bir geçiş içermektedir. Ancak hareket desenleri incelendiğinde her üç duyguda da birbirine benzer şekilde hızlanan zaman çaba niteliği kullanılmaktadır. Hayri, hareket desenin başındaki öfkeli duygu durumunda (03:00 -03:05) beş saniye içerisinde beş ayrı duruş sergilemekte ve her uç poz arasında geçişi ortalama sekiz-dokuz karede yapmaktadır. Hareket desenin son bölümünü oluşturan üzüntülü duygu durumunda ise (03:1703:21) dört saniye içerisinde beş uç poz arasında geçişleri ortalama on iki karede yapmaktadır.
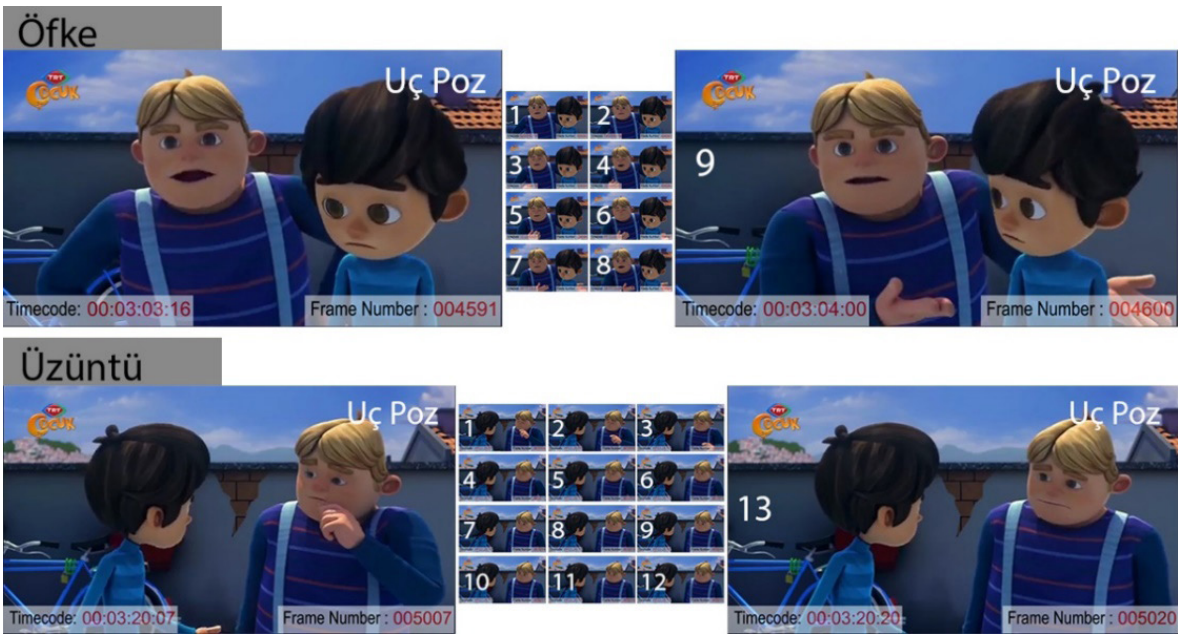

Görsel 6: Öfke ve Üzüntü duygularının hareket desenleri üretiminde uç poz geçişlerinde zaman çaba niteliklerinin kullanımı (Yasin Arslan kişisel arşivi)

Görsel 4-4’te görüldüğü gibi Hayri öfkeli duygu durumunda sergilediği iki uç poz arasındaki geçişi dokuz karede, üzgün duygu durumunda ise iki uç poz arasındaki geçişi on üç karede tamamlamaktadır. Her iki örnekte de hızlanan zaman çaba niteliği kullanılmıştır. Bu sahnede sıklıkla kullanılan hızlanan zaman çaba niteliği ile sürekli aciliyet içerisinde, telaşı, enerjik bir durum yaratılmaktadır. Ancak karakter bu sahnede telaş ve enerji gerektiren öfke duygusunun yanında üzüntü duygusunu da yaşamaktadır. Bu sahnenin başında öfke duygusu hızlanan zaman çaba niteliği ile desteklenirken üzüntü duygusu yavaşlayan zaman çaba niteliği ile desteklenmesi karakterin iç dünyasının yansıtılmasında etkili bir hareket deseni sunabilir. Ayrıca sahnenin hareket tasarımında hızlanan ve yavaşlayan zaman çaba niteliğinin birlikte kullanılması ile sahnenin ritmi de düzenlenebilir. LMA yönteminin, hareket tasarım sürecinde hızlanan ve yavaşlayan zaman çaba niteliğinde yapılacak tercihler ile öfke ve neşe duygularının desteklenmesinde estetik çözümler sunulacağı düşünülmektedir.

\subsubsection{Akıș}

Hayri'nin hareket desenleri LMA yöntemi akış çaba faktörü kapsamında incelendiğinde 
serbest akış çaba niteliğinin yoğun bir şekilde kullandığı görülmektedir. Tasarlanan karakteristik özellikleri gereği, Hayri'nin enerjik ve hareketli bir iç dünyası vardır ve hareket desenlerinde genelde tercih edilen serbest akış çaba niteliği onun bu yönünü destekler niteliktedir. Örneğin basket maçında takım arkadaşlarına taktik verdiği sahnede (09:39) Hayri'nin serbest akış çaba niteliği kullandığı görülmektedir. Hayri, bu sahnede yaklaşık altı saniye içerisinde altı farklı poz arasında geçiş yapmaktadır (Görsel 4-5).
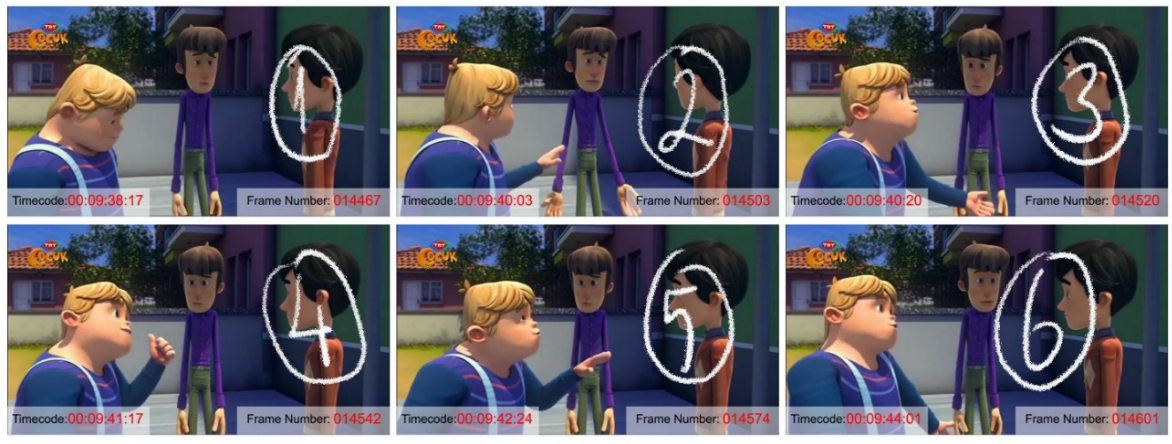

Görsel 7: Hayri'nin hareket desenlerinde uç poz tasarımında serbest akış çaba niteliğinin kullanımı (Yasin Arslan Kişisel arşivi)

Hayri'nin bu sahnedeki hareket desenlerini oluşturan her bir poz arasındaki geçişler esnasında hareketin engellenemez nitelikte olduğu görülmektedir. Bir diğer ifade ile Hayri, bir pozdan diğerine büyük değişimle ve enerjik bir şekilde sıçrayarak ilerlemektedir. Hayri'nin bu hareket deseninde kullanmış olduğu serbest akış çaba niteliği karakterin iç dünyasındaki enerjik yapısını desteklemektedir. Hayri içindeki enerjiyi serbest bırakmışçasına bir pozdan diğerine geçmektedir. Ancak Hayri'nin hareket desenlerinde serbest akış çaba niteliği sürekli kullanılmaktadır. Örneğin

Görsel 4.4'te üç farklı duygunun art arda verildiğine değinmiştik. Bu sahnede öfke, şaşkınlık ve üzüntü duyguları için farklı akış çaba niteliklerinin kullanılması karakterin içinde bulunduğu duygunun desteklenmesini sağlayabilir. Bu sahnede öfke ve şaşkınlık duyguları serbest akış çaba nitelikleri ile desteklenebilir. Bu duyguları takip eden üzüntü duygusu ise bağlı akış çaba niteliği ile desteklenerek hareket desenleri ve karakterin iç dünyası arasında tutarlılık sağlanabilir. Hayri'nin hareket desenlerinde genelde yukarıdaki örneklere benzer şekilde bir akış çaba niteliği kullanımı görülmektedir.

\subsubsection{Ağırlık}

Hayri'nin hareket desenleri LMA yöntemi ağırlık çaba faktörü kapsamında incelendiğinde aktif ağırlık çaba niteliğinin yoğun bir şekilde kullandığı, pasif ağırlık çaba niteliğinin ise aktif ağırlık çaba niteliğinden daha az kullanılmadığı görülmektedir. Hareket desenlerinde tercih edilen aktif ağırlıkta ise güçlü ağırlık çaba niteliğine zayıf ağırlık çaba niteliğinden daha yoğun yer verilmiştir. Ancak Hayri'nin hareket desenlerinde aktif ağırlık çaba niteliğinin uygulanmasında teknik olarak hatalar yapıldığı gözlemlenmektedir. Örneğin Hayri'nin grup arkadaşları ile aşağı mahalleye indiği ve kendilerine benzeyen diğer çocuklarla karşılaştığı sahnede (05:53), Hayri iki üç 
adım atarak diğer karakterlere doğru yaklaşır. Bu sahnede Hayri'nin hareket deseninin üretiminde teknik hataların yapıldığı görülmektedir (Görsel 4-6). Hayri kilolu ve ağır bir bedene sahip olmasına rağmen yürüme hareket deseninde havada yüzercesine ilerlemektedir. Bu sahnede Hayri'nin iç dünyası incelendiğinde, hareket deseninde ağırlığının bilinçli olarak hafifletilmesini gerektirecek bir duygu, düşünce ya da dürtünün olmadığı görülmektedir. Bu sahnede, hareket deseninin uç pozlarında ağırlık ve denge kavramlarının uygun şekilde kullanılmamasından kaynaklanan teknik bir hata vardır. Hareket deseninin üretiminde yapılan bu teknik hata nedeniyle, güçlü ağırık çaba niteliği sergilemesi gereken Hayri'nin, tam tersine zayıf ağırlık çaba niteliği sergilediği görülmektedir. Hayri'nin zayıf ağırlık çaba niteliği sergilemesi nedeniyle de bu sahnedeki hareket deseninde ağırlık hissi yoktur.
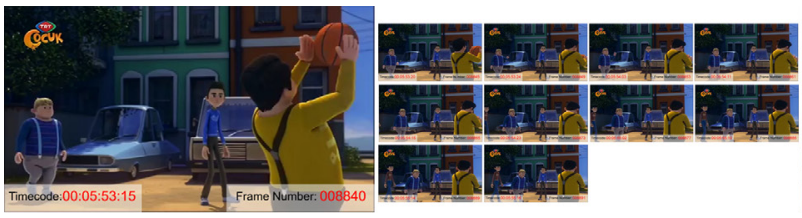

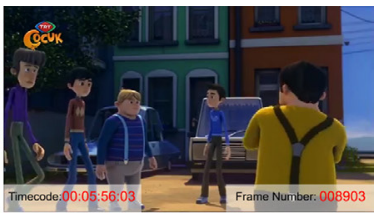

Görsel 8: Hayri'nin hareket desenlerinde ağırlık çaba faktörünün kullanımı (Yasin Arslan Kişisel arşivi)

Hayri'nin hareket desenlerinin üretiminde ağırlık ve denge gibi temel konularda görülen eksikler nedeniyle Hayri'nin hareket desenleri, LMA yönteminin çaba unsuru kapsamında analiz edilirken ağırlık çaba faktörü değerlendirme dışında tutulmuştur. Hayri'nin hareket desenlerinde gözlemlenen ağırlık ve denge eksiklikleri, projenin diğer karakterlerinin hareket desenlerinde de benzer şekilde gözlemlenmektedir.

Hayri'nin çizgi dizi projesindeki hareket desenleri genel kapsamda ele alındığında LMA yöntemi çaba unsurunda hızlanan zaman, doğrudan uzay ve serbest akış çaba niteliklerinin yoğun bir şekilde kullanıldığı, ancak yavaşlayan zaman, dolaylı uzay ve bağlı akış çaba niteliklerinin ise tercih edilmediği söylenebilir. Bununla birlikte ağırlık çaba niteliği kullanımında, animasyon üretim tekniklerindeki temel eksiklikler nedeniyle değerlendirilememiştir. Hayri'nin hareket desenlerinde yoğun gözlemlenen LMA yöntemi çaba unsurundaki; uzay, zaman ve akış çaba faktörleri kullanımının karakterin iç dünyasını oluşturan duygu, düşününce ve dürtüyü desteklemek yerine önceden belirlenen genel bir hareket tarzını desteklemek amacıyla kullanıldığı söylenebilir. Önceden belirlenen bu hareket tarzında ise belirli uzay, zaman ve akış niteliklerinin kullanımına odaklanıldığı görülmektedir. Hayri'nin hareket desenlerinde belirli bir hareket tasarımını elde etmek amacıyla tercih edilen uzay, zaman ve akış çaba niteliklerinin, çizgi dizi projesinin diğer karakterlerinde de benzer şekilde kullanıldığı görülmektedir. Hareket desenlerinde yapılan benzer tercihler nedeniyle çizgi dizi karakterlerinin tamamında karakterin iç dünyasındaki duygu, düşünce ve dürtüye bakılmaksızın benzer hareket tarzı kullanılarak hareket desenlerinin tasarlandığı söylenebilir. 


\section{Sonuc}

Animasyon sineması teknolojinin gelişimi ile birlikte hızlı bir dönüşüm içerisindedir. Bu dönüşüm sonucunda hareket üretim süreçleri de değişmekte ve çok katmanlı karmaşık bir süreç haline gelmektedir. Bu gelişmelerle birlikte günümüz animasyon sinemasında karakterin duygu ve düşüncelerinin seyirciye aktarılması önem kazanmıştır. Karakterlerin duygu ve düşüncelerinin izleyiciye ulaştırılmasında Animasyonun 12 Prensibi dışında Animasyonun Elemanları, LMA yöntemi gibi yenilikçi yaklaşımlar da kullanılmaktadır. Bu yenilikçi yaklaşımlardan LMA yöntemi karakterin iç dünyasını kaplayan duygu ve düşüncenin seyirciye ulaştırılması noktasında diğerlerinden ayrılmaktadır. Bu çalışmada "Rafadan Tayfa" çizgi dizi projesinin en çok izlenen bölümlerinden "Rafadan Rafadana Karşı" bölümünde, ana karakterlerden Hayri'nin hareket desenleri LMA yönteminin çaba unsuru kapsamında ele alınmış ve karakterin iç dünyasını yansıtması bakımından değerlendirilmiştir. Bu değerlendirme sürecinde LMA yöntemi uzay, zaman ve akış çaba faktörleri kapsamında hareket analizleri yapılmıştır. Ancak hareket desenlerini oluşturan ana pozlarının tasarımında, denge (balance), yaylar (arcs) ve ağılık değişimi (weight shift) gibi animasyon ilkelerinin uygulanmasında görülen temel hareketlendirme hataları nedeniyle ağırlık çaba faktöründe değerlendirme yapılamamıştır. Hareket desenleri, LMA yönteminin uzay, zaman ve akış çaba faktörlerinde elde edilen veriler ışığında değerlendirilmiştir.

Uzay çaba faktöründe dolaylı uzay çaba niteliği yoğun şekilde kullanılmış, doğrudan uzay çaba niteliğine ise dolaylı uzay çaba niteliğinden daha az yer verilmiştir. Uzay çaba faktöründe yapılan bu tercihler ile esnek ve mekânın tamamını kullanan çok yönlü hareket desenleri elde edilmiştir. Ancak sahne içerisinde karakterin odaklanması gereken durumlarda doğrudan uzay çaba niteliği yerine kullanılan dolaylı uzay zaman çaba niteliği nedeniyle karakterin iç dünyası ile örtüşmeyen hareket tasarımlarının ortaya çıktığı görülmüştür. Hareket desenlerinin tasarımındaki bu tek yönlü yoğun kullanımdan kaynaklanan karakterin iç dünyasını yansıtan duygu-düşünce ile tasarlanan hareket deseni arasında kopukluklar olduğu görülmektedir. Hareket tasarım sürecinde, uzay çaba faktöründe tek yönlü kullanım yerine karakterin iç dünyasına hâkim olan duyguya uygun uzay çaba niteliğinin kullanılması ile izleyiciye aktarılmak istenen duygu ve düşüncenin desteklenebileceği düşünülmektedir.

Zaman çaba faktöründe tek düze bir şekilde hızlanan zaman çaba niteliğinin kullanılması sahnelerin ritminin düzenlenmesinde bir sorun olarak karşımıza çıkmaktadır. Hayri'nin genel hareket desenlerinde yapılan zaman kullanımı sürekli aciliyet içerisinde bir pozdan diğerine sıçrayan bir hareket tasarımı ortaya koymaktadır. Bu hareket tasarımını üretmek için yoğun bir şekilde Animasyonun 12 Prensibinden yavaşlama (slow in) ve hızlanma (slow out) kullanılmaktadır. Eğitmen Peter Ratner hareket desenlerinde yavaşlama ve hızlanmanın prensiplerinin yoğun kullanımının hareket desenlerine estetik anlamda çeşitlilik katmak yerine tam tersi statik ve benzer hareket desenlerinin ortaya çıkmasına neden olduğunu vurgulamaktadır (Ratner, 2003, s. 303). Rafadan Tayfa çizgi dizi projesinde de zaman çaba faktöründe yapılan tercihler nedeniyle karakterlerin sürekli ve yoğun bir hareket içerisinde olmasına neden olmakta ve hareket çeşitliliğinden yoksun kalmaktadır. Sonuç olarak hızlanan ve yavaşlayan zaman çaba niteliklerinin kullanımı ile (durağan ve enerjik hareket desen- 
lerini içeren) yakalanabilecek estetik bir ritim yerine sürekli ve yoğun hareket desenleri yaratılmaktadır.

Akış çaba faktöründe serbest akış çaba niteliği yoğun şekilde kullanılmış ve bağlı akış çaba niteliğine ise serbest akış çaba niteliğinden daha az yer verilmiştir. Akış çaba faktöründe yapılan bu tercihler hareketin enerjik ve durdurulamaz nitelikte sürekli bir şekilde ilerlemesine neden olmaktadır. Ancak sahnedeki ana duygunun aktarımında enerjinin serbest bırakıldığı dinamik hareket tasarımları ile birlikte enerjinin hapsedildiği kontrollü hareket tasarımlarına da ihtiyaç duyulmaktadır. Karakterin hareket tasarımlarında diğer çaba faktörlerindekilere benzer şekilde akış çaba faktöründe de yapılacak tercihler ile sahnenin ritminin yaratılmasına katkı sağlanabilir. Bu şekilde karakterin iç dünyasını oluşturan duygu, düşünce ve dürtü ile hareket desenleri tutarı hale getirilerek izleyiciye daha güçlü bir şekilde aktarılabilir.

Çalışmada Hayri karakterinin hareket desenlerinde LMA yönteminin çaba niteliğini oluşturan uzay, zaman, akış ve ağırlık çaba faktörlerinde kullanılan özelliklerin diğer karakterler için de kullanıldığı dikkat çekmektedir. Uzay, zaman, akış ve ağırlık çaba faktörlerinde yapılan tek yönlü tercihlerin proje içerisinde ortak bir hareket tasarımı yakalama amacıyla kullanıldığı düşünülmektedir. Ancak tüm karakterlerin hareket tasarımında ortak bir dil yakalamak adına yapılan bu tercihlerin aşağıdaki sonuçları ortaya koyduğu söylenebilir;

Hayri karakteri farklı durumlarda aynı hareketi tekrarlamakta, bu da karakterin inandırıcılığını azaltmaktadır.

- $\quad$ Karakterlerin iç dünyasını oluşturan tasarım bileşenlerine (sosyolojik, psikolojik ve fizyolojik özellikler) ve sahnenin içerdiği duygu, düşünce veya dürtüye bakılmaksızın tüm karakterler benzer hareket tasarımları sergilemektedir.

- $\quad$ Sahnede karakterin iç dünyasını oluşturan duygu, düşünce veya dürtü ile hareket desenleri arasındaki tutarlığın ortadan kalkarak aktarımak istenen duygunun seyirciye ulaştırımasında bir engel oluşmaktadır.

Yukarıda yer verilen eksiklikler, hareket tasarımı yapılan karakterin izleyiciye aktarması beklenen duygu, düşünce ve dürtünün karakterin kendi özgün hareket desenleri ile ulaştırmasına engel olmaktadır. Bu durum hikâyenin genel olay akışını kesintiye uğratmakta ve seyirci ile karakter arasında bağlantı kurulmasını engellemektedir. Seyirci ve karakter arasında bağlantının kurulması ise ancak karakterin iç dünyasına hâkim duygu, düşünce ve dürtünün yine karakterin kendine özgü tasarlanan hareket desenleri ile tutarlı olması ile sağlanabilir.

Rafadan Tayfa çizgi dizi projesinde Hayri karakterinin hareket tasarımında LMA yönteminde kullanılarak tespit edilen bu eksikliklerin yanında yenilikçi yaklaşımların olduğu görülmektedir. 2010 sonrası animasyon sinemasında, genel kabul gören gerçekçi üç boyutlu görüntü ve hareket estetiği yakalama hedefinin dışına çıkma amacıyla öncü çalışmalara yer verildiği görülmektedir. Paperman (Pixar/Walt Disney-2012), The Peanuts Movie (Blue Sky-2015) ve Spiderman: Into the Spider-Verse (Sony Pictures-2018) gibi son dönem animasyon sinemalarında bu yaklaşımın örnekleri görülmektedir. Rafadan Tayfa çizgi dizi projesinde de diğer 3D animasyon sineması 
örneklerinden farklı yaklaşımların olduğu söylenebilir. Örneğin, Rafadan Tayfa çizgi dizisi hareket tasarımında, son dönem animasyon sinemasındaki eğilimlere benzer şekilde geleneksel animasyon sinemasında kullanılan hız çizgileri (speed lines), iki boyutlu animasyon tekniği ile üretilen duman, toz vb. efektlerin kullanımına yer verilmektedir. Rafadan Tayfa çizgi dizi projesindeki hareket tasarımında yapılan bu tercihler ülkemiz animasyon sektöründe yenilikçi yaklaşımlar olarak değerlendirilebilir. Projede gözlemlenen bu yenilikçi yaklaşımların, karakter animasyonu üretim sürecinde LMA yöntemi kullanılarak tasarlanacak hareket desenleri ile desteklenerek seyirciye ulaşabilen özgün bir çalışma ortaya çıkabileceği ve Türk animasyon sektörüne katkı sağlayabileceği düşünülmektedir.

\section{Kaynakça}

Akyürek, F. (2004). Senaryo Yazarı Olmak: Senaryo Yazmak. Meiacat Yayıncılık: İstanbul.

Arslan, Y. (2019). "Animasyon Sinemasında Laban Hareket Analizinin (LMA) Duygu Aktarımında Kullanımı: 3 Boyutlu Bilgisayar Animasyon Sahnesi Örneği” Yüksek Lisans Tezi. Eskişehir, Türkiye: Anadolu Üniversitesi Güzel Sanatlar Enstitüsü.

Bishko, L. (1991). The Use Of Laban Movement Analysis for the Discussion of Computer Animation. Dance and Technology-1, 1-9.

Bishko, L. (2007, 12 09). The Uses and Abuses of Cartoon Style in Animation. 01 23, 2017 tarihinde www.journal.animationstudies.org: https://journal.animationstudies.org/leslie-bishkothe-uses-and-abuses-of-cartoon-style-in-animation/ adresinden alındı

Bishko, L. (2014). Animation Prenciples and Laban Movement Analysis: Movement Frameworks for creating Empathic Caharacter Performance. J. Tanenbaum, M. S. El-Nasr, \& M. Nixon içinde, Nonverbal Communication in Virtual Worlds: Understanding and Designing Expressive Characters (s. 177-203). Pittsburgh: ETC Press.

Bishko, L. (2017, 10 08). www.infomus.org/pub/Cues/mpulsivita/Leslie_Bishko.pdf. www. infomus.org. adresinden alındı

Davies, E. (2006). Beyond Dance: Laban's Legacy of Movement Analysis. New York: Routledge, Taylor\&Francis Group.

Furniss, M. (1998). Art in Motion Animation Aesthetics. London: John Libbey \& Company Pty Ltd.

Gibbs-Kundert, John \& Gibbs-Kundert, Kristing. (2009). Action: Acting Lessons for CG Animators. Indianapolis: Wiley Publishing, Inc.

Hooks, E. (2003). Acting for Animators; A Complate Guide to Performance Animation. Portmouth: Heinemann.

Jones, A., \& Oliff, J. (2007). Thinking Animiation. Boston: Thomson Course Techology.

Lasseter, J. (1987). Prenciple of Traditional Animation Applied to 3D Computer Animaiton. Computer Graphics, 35-45.

Moore, C. L. (2009). The Harmonic Structure of Movement, Music, and Dance According to Rudolf Laban. New York: The Edwin Mellen Press.

Newlove, J. (1993). Laban For Actors and Dancers: Putting Laban's Movement Theory into Practice. New York: Routledge.

O'Connor, D. (2018, Nisan 23). Angry Animator: Showcasing The Work of Dermot O Connor, 
Cartonist. angryanimator: http://www.angryanimator.com/word/2018/04/23/21-foundations-ofanimation/ adresinden alındı

Osborne, M., \& Steveson, J. (Yönetenler). (2008). Kung Fu Panda [Sinema Filmi].

Potter, N. (2002). Movement for Actors. New York: Allworth Press.

Ratner, P. (2003). 3-D Human Modelling and Animaiton. New Jersey: John Wiley\&Sons.Inc.

Stanislavski, K. (2012). Oyuncunun El Kitabı. (O. Akınhay, Çev.) İstanbul: Agora Kitaplı̆̆ı.

Sutil, N. S. (2013). Rudolf Laban and Topological Movement: A Videographic Analysis. Sapce and Culture, 173-193.

Thomas, Frank and Johnston, Ollie. (1981). The Illusion of Life: Disney Animation. New York: Walt Disney Productions.

Wells, P. (1998). Understanding Animation. London: Routledge.

\section{İnternet Kaynak:}

http-1: https://www.youtube.com/playlist?list=PLA5dyskGy4ct1sc-jEiA_IJb-1hGhFT5K, TRT Çocuk, Rafadan Tayfa youtube kanalı (Erişim Tarihi: 04.02.2019/18:00)

http-2: http://www.beyazperde.com/diziler/dizi-21238/fotolar-detay/?cmediafile=21360062, Rafadan Tayfa karakterleri (Erişim Tarihi: 22.02.2019: 01:52)

http-3: https://www.facebook.com/rafadantayfa/photos/a.1589894307906722/

1615109072051912/?type=1\&theater , Erişim Tarihi: 09.05.2019) 